\title{
Metaphor Usage in Early Press Coverage of Nanotechnology: Turning Science into Soccer Balls and Human Hair
}

\author{
Toby A. Ten Eyck ${ }^{*}, 1$ and Paul Hernandez ${ }^{2}$ \\ ${ }^{I}$ Department of Sociology and Michigan State University Extension, Michigan State University, East Lansing, MI 48824, \\ USA \\ ${ }^{2}$ Department of Sociology, Michigan State University, East Lansing, MI 48824, USA
}

\begin{abstract}
The development of new discourses is often an interpretative process among both practitioners and onlookers, whether one is studying an emerging technology or press coverage of a new issue. This paper provides an insight into how nanotechnology was introduced to the public beginning in the 1980s through the early years of the twenty-first century by investigating the use of metaphors in the popular press throughout the US. To make nanotechnology understandable to the lay public, much of the coverage was tied to popular cultural items and metaphors such as soccer balls (what nanotech particles "looked" like) and human hairs (relative size of these particles). It was found that positive, or at least harmless, metaphors far outweighed negative images (e.g., gray goo) in the coverage, leading to the conclusion that any potential dangers tied to nanotechnology were both overlooked by the press and unavailable to the public.
\end{abstract}

\section{INTRODUCTION}

According to Hewlett-Packard advertising, nanotechnology offers the potential of making a cell phone small enough for an ant to use, and computer chips the size of a wristwatch which could contain every book ever written. Are these, however, real promises of an exciting new future, or another hollow endorsement about a new technology parallel to Lewis L. Strauss's proclamation that nuclear fusion energy would be too cheap to meter? The aim of this paper is to study the ways in which nanotechnology was introduced to the public in its first twenty years of coverage in the US press through a study of the metaphors used by journalists.

The conceptual framework for thinking about this topic is based on the work of Zelizer [1,2] and the media as a dramaturgical producer/director which provides scripts and program guides for audience members [3]. Zelizer is concerned with journalists as an interpretative community, drawing on previous journalistic practices to make sense of their own work. The inclusion of dramaturgy helps to understand the ways in which both journalists and their sources are trying to present nanotechnology to an audience. This is not to say that audience members are cultural dupes and believe everything they are seeing in the news, but given the lack of cultural resonance regarding nanotechnology, we are assuming that at least some of the information being presented is used by some audience members to make sense of the technology. Before turning to a more in-depth discussion of these concepts and our data, we will briefly touch on the topic of nanotechnology.

*Address correspondence to this author at the Department of Sociology and National Food Safety and Toxicology Center, 316 Berkey Hall, Michigan State University, East Lansing, MI 48824, USA; Tel: 517-353-8671; Fax: 517-432-2856; E-mail: teneyck@msu.edu

\section{Nanotechnology}

Nano refers to the magnitude of one-billionth, rendering nanoseconds and nanometers as nearly no time or no space. The term nano, according to the online edition of the Merriam-Webster Dictionary (http: //www.merriam-webster. com/dictionary/nano, accessed 10/10/2007), is of Greek origin and translates roughly to "dwarf." In short, the term has ancient roots, while the technology is relatively new. Given our interest in metaphors and presentations of new ideas, it should be noted that even scientific organizations have used lay language to clarify the idea. In a call for proposals for a program in nanoscale science and engineering, the National Science Foundation defined nanotechnology in the following manner: "One nanometer (one billionth of a meter) is a magical point on the dimensional scale. Nanostructures are at the confluence of the smallest of human-made devices and the largest molecules of living systems" (http: //www.nsf.gov/pubs/ 2003/nsf03043/nsf03043.txt, accessed September 24, 2007). It is interesting to see a major science funding source use the term "magical."

The possibility of developing materials at the nano level has gained attention in many fields -- from medicine to textiles [4]. The investment opportunities seem limitless from an industry vantage point, and some venture capitalists have already jumped on the bandwagon [5]. At the same time, the Center for Responsible Nanotechnology (CRN) was launched in 2002 (Nanoparticle News 2003) with the following mission statement:

We believe that even a technology as powerful as molecular manufacturing can be used wisely and well, but

\footnotetext{
${ }^{\mathrm{i}}$ The idea of conducting science and engineering at the nano level was first introduced by Richard Feynman in 1959 [29].
} 
that without adequate information, unwise use will be far too common. The mission of $\mathrm{CRN}$ is to raise awareness of the issues presented by nanotechnology: the benefits and dangers, and the possibilities for responsible use. (www.crnano.org, accessed October 15, 2008).

It should be noted that there are concerns with nanotechnology, involving environmental degradation, privacy issues, and human health (nanotubes have been found to block the windpipes of mice in laboratory experiments) [6,7]. Still, much of the early information about this technology was positive. The point is that nanotechnology has been promoted as not only a good thing, but a good thing for many people in various fields of research and industry. It is argued, however, that it will be the buying public that will determine its fate. ${ }^{\text {ii }}$ Since we assume that most people are not conducting experiments on nanotechnology at home, we look to the media for the public presentations of this new technology.

\section{Interpretative Communities and Scripts}

Everything has appearance and essence, shell and kernel, mask and truth. What does it say against the inward determination of things that we finger the shell without reaching the kernel, that we live with appearance instead of perceiving the essence, that the mask of things so blinds us that we cannot find the truth? [8].

What is the truth about nanotechnology? And, if we are not nanotechnologists ourselves, how do we determine what is a shell and what is a kernel when reading or hearing about this new technology? One of the more salient organizations which disseminate information in our modern society on topics such as nanotechnology is the mass media $[9,10]$. We are aware that surveys have shown that the media are not necessary trusted sources of information on topics such as biotechnology, while scientists are typically viewed as appropriate information sources [11]. The problem with these findings is that most people are not talking directly to scientists, but are hearing and/or reading about their work in the media. For this reason, we will focus on what the media are saying about nanotechnology with the assumption that this is an important source of information. Whether or not it is the kernel or the shell of truth is something the reader must decide.

Coverage of science and technology in the popular press is as old as the popular press itself [12], including the coverage of scientific controversies [13]. Given this history, one could argue that journalists would begin with contentions and conflicts whenever a new science or technology is introduced to the public. This echoes Zelizer's $[1,2]$ work on journalists covering such stories as Edward R. Murrow challenging Senator Joseph McCarthy, the Watergate scandal, and the John F. Kennedy assassination. Zelizer has argued that past practices are interpreted by current journalists, providing guidance for how journalistic work is to be accomplished. Those practices that were deemed unsuccessful are ignored or avoided, while those that

\footnotetext{
${ }^{\mathrm{ii}}$ This is an oversimplification of consumerism. While the buying public can
} choose to make a purchase, larger corporations present the options. gain rewards are copied. It should also be noted that some of these interpretations change over time. The reporters who originally broke the Watergate story (Woodward and Bernstein) were first shunned by other reporters, until they started gaining notoriety for their work. This led to a reinterpretation of their work, and other reporters began copying their style, which included gaining access to information illegally in some cases, and protecting sources that may have been conducting illegal activities themselves [2].

Research on the coverage of technological issues, however, does not seem to show this kind of trajectory. Instead, each new technology begins from a 'gee-whiz' perspective before giving voice to (potential) opponents [13, 14]. What seems to be key in this finding is not the story itself but the role of source organizations. For many science and technological innovations, the only people familiar with the topic are scientists. Since many of these scientists were with large organizations such as the government or universities, ties to reporters were much closer [15]. Tuchman [16] argued that reporters do not want to strain relationships with important sources positioned in major organizations, and the same may have been happening with nanotechnology in the early years.

Turning to the audience, as it is believed that the media do affect people $[17,18]$, studies have shown that people are already forming ideas about nanotechnology [19], though it is not our intention to discuss public opinion. Instead, we want to focus on the things that were said about nanotechnology to get a sense of the scripts that were being provided for people reading these stories. This comes from Goffman's [20] work on dramaturgy and Gamson's [21] ideas about cultural resonance, the latter arguing that we tend to rely more heavily on media discourse when a topic is unusual or new to us. Most of us do not have experiential knowledge with the topic of nanotechnology, and it is too new to be part of our public wisdom (though there are stories about dwarfs and other small things in our culture). Goffman [20] argued that we try to present aspects of the self that people will find likeable or appropriate, which could include being well-informed about new issues and ideas. To know about nanotechnology is to have read the papers and surfed the web. While there is a great deal of information on the web about nanotechnology (over 53 million Yahoo! hits in May 2008), we are going to stick to newspapers, as the beginning of the coverage started just prior to the Internet revolution.

We do not want to overstate the role of the media in shaping public opinion. Nanotechnology is very possibly something that many individuals are ignoring (for various reasons). In addition, we assume that there are people who are (re)interpreting the information that is available, shaping it to fit their own ways of thinking that would have little resemblance to the original story. At the same time, we contend that Pratkanis and Aronson's [18] work on persuasion and indirect pathways could be appropriately applied to this situation, as nanotechnology would be a topic for which information is available and visible, and people are getting pieces of it (e.g., through a headline, hearing parts of a story on the news while taking a shower). This indirect access limits conscious efforts to critically think about the 
issue, leaving the scripts provided by the media as the most appropriate mental schemas if its salience is increased, such as when answering questions on a survey or someone at work brings up the topic.

Another important aspect of persuasion, or at least knowledge acquisition, is understandability or familiarity [18]. Metaphors are a tool used to make the unknown known. Jenner and Scott [22], for example, found that patients with Hepatitis $\mathrm{C}$ used metaphors to make sense of various medical treatments for their disease. This work also showed that metaphors were connected to underlying beliefs in the medical field. Patients who believed in the Western biomedical model used different metaphors than those who were either unsure of the biomedical model or believed in more non-traditional methods. This should be taken into consideration when dealing with media scripts. While many metaphors are probably provided to reporters by those who are trying to make something understandable, it is still interesting to approach this from the idea that metaphors represent larger value systems. In describing something as small as a nanoparticle, a metaphor such as "smaller than a wasp's stinger" is as appropriate as "smaller than the width of a human hair." The imagery, however, is not similar. One represents pain while the other calls to mind something most humans share and is basically benign. In short, metaphors are not value neutral, but, as with Jenner and Scott's patients, offer insights into the values systems. In this case, the values of US science and journalism.

\section{DATA AND METHODS}

We used Lexis-Nexis to search for all articles on the topic beginning in the 1980s for all US newspapers. We agree with Gans [23] that newspapers such as the New York Times and Washington Post are the newspapers of national record, but wanted to see if local and national news on this topic were similar [24]. Using nanotech! (“!” is a wild card character) as the search term, the first article appeared in 1986. We found that our search term picked up a large variety of articles, including articles with the term "buckyballs", though such articles were not used unless there was some link to the term "nano", such as information concerning the Nanophase Company. While it could be argued that readers would not relate something like "Nanophase" with nanotechnology, the point is that during this time the term "nano" was being tied to everything from businesses to thoughts about computers and medicine.

We searched all US news archived in Lexis-Nexis from 1986 to 2004, uncovering a total of 4,248 articles. For the early years, we coded every article, until more than 100 articles appeared in a given year. At that point, we coded 100 articles from each year, by rolling a die, coding the article that appeared in that year that corresponded with the article, and then coding articles based on intervals (we actually coded 102 articles for 2001 and 2002 based on this process). For example, if we had 200 articles in one year, we would code ever second one after the first one coded from the die (so, if we rolled a four, we coded the fourth, sixth, eight, and so forth). We also weighted the articles by region. For example, if the West and Northeast each had 100 articles one year, and the Midwest and Southeast each had 50 (a total of 300 articles for the year), we would code 33 from the
Northeast, 33 from the West, 17 from the Midwest, and 17 from the Northeast. Using this procedure we coded 683 articles, of which 225 were coded as having used metaphors. Table 1 contains the total number of articles appearing each year. It is interesting to note that the year 2000, the first year in which over 100 articles appeared, $50 \%$ of the articles used metaphors, but this dropped to $28 \%$ the following year. In fact, the second highest percentage of metaphors after 2000 was found in 2003, when $34 \%$ of the articles contained metaphors. Whether this is a reflection of journalistic practices as reporters no longer felt the need to provide explanations for nanotechnology after the initial push, or that source organizations stopped providing metaphors is an open question and, unfortunately, beyond the scope of this paper.

Table 1. Press Coverage Intensity of Nanotechnology - 19862004

\begin{tabular}{|c|c|}
\hline Year & Number of Articles \\
\hline 1986 & 2 \\
\hline 1987 & 1 \\
\hline 1988 & 1 \\
\hline 1989 & 0 \\
\hline 1990 & 2 \\
\hline 1991 & 0 \\
\hline 1992 & 3 \\
\hline 1993 & 6 \\
\hline 1994 & 1 \\
\hline 1995 & 2 \\
\hline 1996 & 32 \\
\hline 1997 & 21 \\
\hline 1998 & 33 \\
\hline 1999 & 75 \\
\hline 2000 & 239 \\
\hline 2001 & 415 \\
\hline 2002 & 757 \\
\hline 2003 & 1169 \\
\hline 2004 & 1490 \\
\hline
\end{tabular}

The coding scheme for the overall project consisted of twenty-one variables, including length of article, source of information, whether or not a metaphor was used to describe nanotechnology, and the overall slant of the article. Given our interest in metaphors in this article, we went back and coded the metaphors in themes and whether the metaphor seemed positive (the wasp vs. hair scenario). Some terms, such as bacteria, are more difficult to code, as there are both good and harmful bacteria in our environment. In such cases, we re-read the article, and made a decision on whether the context of the article provided a better understanding of how nanotechnology was being portrayed. 


\section{The Metaphors}

\section{Quantitative Analysis}

It should be noted at the beginning that over half of the articles $(54.9 \%)$ in our sample were considered somewhat or very positive, $39.7 \%$ were considered neutral or balanced, and only $5.4 \%$ were coded as either somewhat or very negative. Of the 15 very negative articles, only one used a metaphor, while for the 175 very positive articles, 117 used metaphors. The one very negative article with a metaphor was discussing the possible health concerns with nanoparticles, and discussed the fact that nanoparticles were smaller than human cells (which was part of the problem as it was thought these particles could easy invade and contaminate living cells).

We developed ten categories from the metaphors. Table $\mathbf{2}$ contains the frequencies of these terms. We were able to put each metaphor into a category only once, though these are not mutually exclusive categories. If a phrase such as "smaller than a human hair" was used, we coded this under the heading of "human hair" and not "smaller." categories are self-explanatory, though we did find a few metaphors that did not fit into any of the categories, so were placed in an "other" category, such as the use of the terms "Christmas Tree" and "bionic bozo." The former term was used to describe the structure of a nanoparticle in an editorial piece published on February 18, 2000 in the Bangor Daily News, while the latter was found in an article appearing on July 5, 1987 in the Washington Post which discussed the possibilities of nanotechnology.

Table 2. Metaphor Categories and Frequencies

\begin{tabular}{|c|c|}
\hline Categories & $\boldsymbol{N}(\boldsymbol{\%}$ of 225 total metaphors $)$ \\
\hline \hline General & $59(26 \%)$ \\
\hline Human Hair & $54(24 \%)$ \\
\hline Computers/Machines/Devices & $40(18 \%)$ \\
\hline Soccer Balls/Domes & $25(11 \%)$ \\
\hline Cells/Molecules/Bacteria & $17(8 \%)$ \\
\hline Dust/Sand & $9(4 \%)$ \\
\hline Pins & $8(3 \%)$ \\
\hline Bombs & $5(2 \%)$ \\
\hline Gray Goo & $2(1 \%)$ \\
\hline Other & $6(3 \%)$ \\
\hline
\end{tabular}

The most used metaphors ( $\mathrm{N}=59,26 \%)$ were purely descriptive, including terms such as "ultra tiny," "very small," "ultra small," "microscopic," "itty bitty," and

\footnotetext{
${ }^{i i i}$ We found Garfinkel's [30] work on coding to be pertinent here. For example, a phrase such as "a device so small it can fit in a drop of water," was coded as machine/computer and not as an element such as sand or dust, which were often used to provide a sense of size. Garfinkel mentioned how coding can reify categories that are either nonexistent or at least porous. That is definitely the case when analyzing metaphors in reporting and should be kept in mind.
}

"Lilliputian." Many of these metaphors were combined with terms such as human hair ("smaller than human hair") or cells ("far smaller than human cells"). Human hair was used 54 times $(24 \%)$ to provide a picture of the scale of nanotechnology, while cells were used seven times. The word "dwarf," which is the Greek basis for nano, was used in two articles.

Terms referring to the shape of nanotubes or particles appeared in 25 articles (11\%). This included 23 mentions of soccer balls or balls and two mentions of "Geodesic domes." We assume that things that are tiny and shaped like soccer balls do not strike fear into the hearts of most newspaper readers. As mentioned, the slant of the article would contextualize the metaphor, as things tiny could be problematic. This included discussions of self-replicating nano machines or robots, as found in Michael Crichton's Prey, a Frankenstein-esque story about a top secret nanotechnology program which spins out of control from its creators, leading to self-replicating nanobots that devour a few of the humans for their protein fix.

Nanobots and small machines or computers were used in $40(18 \%)$ of the articles. Terms such as "small robots," "nanobots," or "micro machines" were found in articles dealing with everything from medical applications to computers that were the size of wristwatches or credit cards to the ways in which nanotechnology products would be built. The script is both scale and use, providing readers a sense of the future where everything is smaller. It should be noted that a discussion about the costs of these new products was typically absent.

Another set of metaphors which captured both scale and use revolved around cells and bacteria (17 articles, $8 \%$ of metaphors). In this case, articles typically discussed nanotechnology as smaller than human cells or bacteria, often with the motive of being able to provide a backdrop for medicine or other technologies that would be used to fight bacteria. As mentioned earlier, there were articles that pointed out the potential dangers of introducing something smaller than cells to the body, but this was the exception rather than the rule. We did a case-specific Lexis-Nexis search on asbestos and nanotech!, and found 27 articles during our period under study. Of these, 12 were from regular newspapers such as The New York Times and San Francisco Chronicle. The other 15 articles were wire service reports or specialized papers such as The Metropolitan Corporate Counsel. We will discuss the link between asbestos and nanotechnology below.

Finally, dust, sand, and the heads of pins were used to offer a sense of scale for readers (dust/sand $=9,4 \%$; pins 8 , $3 \%)$. This imagery may frame nanotechnology in a golden light, or at least as a potential savior for the human race given the ubiquitous question about angels and heads of pins. While sand and dust may be irritating, there was very little discussion about nanotubes being irritating. Instead, it was much more typical to read about nanotubes being even smaller than a grain of sand or speck of dust.

The above analysis provides an overview of the metaphors used to describe nanotechnology. For the most part, the imagery used was benign (human hairs and soccer balls) if not useful and helpful ("the Library of Congress 
contained in a device the size of a wristwatch"), though there were a few mentions of gray goo, nano-sized bombs, and out-of-control nanobots. These terms, however, were often framed as science fiction. The following, for example, appeared in the Telegraph Herald (Dubuque, IA) on May 21, 1999.

It sounds like science fiction: Microscopic oil droplets protect patients from germs and viruses by fusing with the dangerous bugs and causing them essentially to explode.

This creation is part of a Star Trek-like field of science called "nanotechnology", creating drugs and other products so minute that researchers have to build them one molecule at a time.

It should be noted that this article actually used the term "nanobombs" in a positive way; these bombs were to be used to kill harmful bacteria and viruses within the human body. In fact, all five articles that used the bomb metaphor were found in 1999 and discussed this same technology, which leads to a question of patterns of metaphor usage.

Table 3 shows the number of metaphors used each year, and what percentage of articles from that year used metaphors. If we disregard the earlier years (before 1999), we see that in 1999 and 2000, at least half of the articles we coded used metaphors. This dropped to $27 \%$ in 2001 , and then $12 \%$ in 2002. Metaphors were used in $34 \%$ of the articles coded in 2003 and 24\% in 2004, which while an increase over 2001 and 2002, does not reach the levels of the earlier years.

Table 3. Number of Articles Using Metaphors per Year

\begin{tabular}{|c|c|c|}
\hline Year & $\begin{array}{c}\text { Number of Articles Using } \\
\text { Metaphors }\end{array}$ & $\begin{array}{c}\text { Total Number of Articles } \\
\text { Coded }\end{array}$ \\
\hline \hline 1986 & 1 & 2 \\
\hline 1987 & 1 & 1 \\
\hline 1988 & 0 & 2 \\
\hline 1990 & 1 & 3 \\
\hline 1992 & 1 & 6 \\
\hline 1993 & 5 & 2 \\
\hline 1994 & 1 & 32 \\
\hline 1995 & 12 & 21 \\
\hline 1996 & 6 & 33 \\
\hline 1997 & 7 & 75 \\
\hline 1998 & 40 & 100 \\
\hline 1999 & 50 & 102 \\
\hline 2000 & 28 & 100 \\
\hline 2001 & 13 & 100 \\
\hline 2002 & 1 & 1 \\
\hline 2003 & 14 & 1 \\
\hline 2004 & 10 & 1 \\
\hline
\end{tabular}

This still tells only part of the story. Table $\mathbf{4}$ shows where different metaphors appeared over time. As mentioned, there were articles in which more than one metaphor was used, though only one was coded. If one looks at the years prior to 1999, the first thing that jumps out is the use of the soccer ball (which includes geometric dome) metaphor. This term was found 25 times, 16 of which appeared in 1998 or before. Other terms, such as hair, appeared in only one article prior to 1999, and then 53 more times between 1999 and 2004 . Metaphors based on devices (tiny computers) and general terms were available to readers throughout the period. Pins, cells (molecules, bacteria) and dust (sand) tended to appear in the later years.

It is also interesting to note the ways in which some of the metaphors clustered. "Nanobombs" appeared five times in 1999 and no other years. iv Devices were big (15) in 1999, and six of the nine articles mentioning dust or sand appeared in 1999. Pins were big in 2000, while hair was the rage starting in 2000 and continued through the rest of the years (a low point of seven in 2003). This kind of clustering of metaphors and news stories has been found in other research $[25,26]$.

\section{Qualitative Analysis}

We have provided some brief accounts of the actual scripts that were available to readers in the news articles analyzed. At this time we turn to a more systematic investigation of the metaphors based on a timeline of appearance. The first article with a metaphor, appearing in The New York Times on August 10, 1986, had this to say about nanotechnology.

Imagine a computer the size of a protein, which can make copies of itself and can build other nanocomputers that guide vast armies of nanomachines, all programmed to assemble, atom by atom, a rocket engine out of raw materials pumped into a vat. Nanomachines programmed to fight infection and repair body tissues could wipe out disease. They could fix televisions, manufacture food and eat pollution.

We really have no idea as to how many people can fathom the size of "a protein," or even its shape. Still, the imagery is about something tiny and self-replicating, and the script is that nanotechnology will be used for rockets, medicine, television, food, and the environment in a positive way. What could be better than watching a rocket launch on television with a full and healthy stomach in a clean environment?

Much of the writing at this time was based on K. Eric Drexler's Engines of Creation, which spilled over into 1987, when there was concern with potential risks from nanotechnology. The following appearing on July 5, 1987 in the Washington Post.

Some might imagine that the greatest risk would be the possibility of a nanotech industrial accident, in which some

\footnotetext{
iv Another Lexis-Nexis search on just the term "nanobomb" uncovered ten articles during this period. Six of the articles were reviews of one film (Knock Off, 1998), three were on the medical technology mentioned in this paper (1999), and one in 2001 discussing the various uses of nanotechnology, including nanobombs that were similar to those discussed in 1999.
} 
Table 4. Types of Metaphors Used Each Year

\begin{tabular}{|c|c|c|c|c|c|c|c|c|c|c|}
\hline Year & General & Hair & Devices & Soccer & Cells & Dust & Pins & Bombs & Gray Goo & Other \\
\hline 1986 & 0 & 0 & 1 & 0 & 0 & 0 & 0 & 0 & 0 & 0 \\
\hline 1987 & 0 & 0 & 0 & 0 & 0 & 0 & 0 & 0 & 0 & 1 \\
\hline 1988 & 0 & 0 & 0 & 0 & 0 & 0 & 0 & 0 & 0 & 0 \\
\hline 1990 & 0 & 0 & 1 & 0 & 0 & 0 & 0 & 0 & 0 & 0 \\
\hline 1992 & 0 & 0 & 0 & 1 & 0 & 0 & 0 & 0 & 0 & 0 \\
\hline 1993 & 2 & 0 & 0 & 3 & 0 & 0 & 0 & 0 & 0 & 0 \\
\hline 1994 & 0 & 0 & 0 & 1 & 0 & 0 & 0 & 0 & 0 & 0 \\
\hline 1995 & 0 & 1 & 0 & 0 & 0 & 0 & 0 & 0 & 0 & 0 \\
\hline 1996 & 3 & 0 & 1 & 7 & 0 & 0 & 1 & 0 & 0 & 0 \\
\hline 1997 & 0 & 0 & 3 & 0 & 0 & 0 & 0 & 0 & 1 & 0 \\
\hline 1998 & 1 & 0 & 0 & 4 & 1 & 1 & 0 & 0 & 0 & 0 \\
\hline 1999 & 7 & 4 & 15 & 2 & 1 & 6 & 0 & 5 & 0 & 0 \\
\hline 2000 & 16 & 11 & 7 & 5 & 2 & 0 & 5 & 0 & 1 & 3 \\
\hline 2001 & 5 & 10 & 5 & 0 & 5 & 1 & 1 & 0 & 0 & 1 \\
\hline 2002 & 1 & 9 & 2 & 0 & 0 & 0 & 1 & 0 & 0 & 0 \\
\hline 2003 & 15 & 7 & 4 & 0 & 6 & 1 & 0 & 0 & 0 & 1 \\
\hline 2004 & 9 & 12 & 1 & 2 & 0 & 0 & 0 & 0 & 0 & 0 \\
\hline
\end{tabular}

bionic bozo escapes from a vat of chemicals and ravages the populace. In fact, the real threat lies not in the potential for inadvertent accidents with nanotechnology, but in the potential for malice and deliberate abuse.

The military, for example, will no doubt take a microscopic look at nanotechnology's potential for growing engines of destruction. "Smart" viruses could be programmed to make germ warfare cheap and strategically effective. Just think (with an appropriate shudder) what terrorists and politicians -- and sometimes it's hard to tell them apart -- could do with that.

Even if only some of the predictions come true, nanotechnology's possible socio-economic effects could severely disrupt traditional social systems, making the agricultural and industrial revolutions look like historical flyspecks. So our worst mistake would be to dismiss this as science fiction.

We are not really sure who the "bionic bozo" is in this story. One would assume it is some nanoparticle run amok, though it could also be the individual or group which is being deliberately malicious or abusive. The story overall is very balanced between killer viruses and ending poverty and hunger, yet balance does not mean answers. The reader is left with the question of what if we dismiss this as science fiction? Are things getting better or worse? There are too many scripts to decipher any kind of answer for these questions.

It was mentioned early that many new technologies are not challenged early in their media careers, and even the above article was regarded at neutral. The first overall negative article in our sample did not appear until 1996 in
The Record, where nanotechnology and science fiction did meet in the following book review, but notice the lack of a metaphor even given the imagery provided.

\section{DEAD BOYS, by Richard Calder; St. Martin's}

Time and space collapse and nearly pull narrative coherence into the void with them in this audacious but sometimes impenetrable sequel to the praised Dead Girls (1995).

The world of the 21 st century is still governed by a "pornocracy" that ritually desexes "dead girls," or women turned into vampiric "dolls" by a nanotech virus.

There, Ignatz Zwakh, hero of the continuing saga, mourns his executed dead girl Primavera by pickling her extracted reproductive organs in a whiskey bottle. His perverse fascination has a purpose.

At the heart of the novel lies a critique of Western capitalism and sexual politics, of how they dehumanize and homogenize all they touch. But it is often difficult to see this point for the prose.

While it might be a bit disturbing to think of desexed, vampiric females cruising our cities' streets and people picking up the hobby of pickling extracted reproductive organs, readers unfamiliar with nanotechnology would have little help in defining the term, other than it can cause major problems.

What was more likely to be found were metaphors about nanotechnology and soccer balls, such as this published on December 8, 1996 in the Boston Globe about Nanotechnology. 
In Texas, a laser-driven molecular stew pot in 1985 yielded bits of nearly inert carbon that were quite unlike the element's only two known molecular forms - graphite and diamond. Days of head-scratching followed, before three chemists concluded they had created a carbon molecule containing 60 atoms and joined together in the fashion of a soccer ball - hence the name of the new material, Buckminster Fullerene, after the designer of geodesic domes who employed similar shapes.

This is a much more benign discussion of nanotechnology, providing readers with images of miniature soccer balls and scientists at work. There is nothing dangerous here; no lab assistants turning into vampires or scientists disemboweling each other. It is simply a new material being discovered in a lab. The story, in fact, is about potential Nobel Prize winners, the highest achievement for many scientists.

By 2000, concerns about the technology were growing, though the metaphors used in the positive articles had been transferred to those raising concerns, such as the following from the Times Union (Albany, NY) on November 24.

The abilities to modify embryonic cells, eavesdrop on the Internet and create swarms of invisibly small robots are among the many high-tech achievements that are stirring alarm. Security experts fear that terrorists could take advantage of the rapid progress in manipulating human genes to unleash a killer plague.

Nanoscience and nanotechnology deal with objects the size of individual atoms and molecules.

Given that new metaphors were in short supply (gray goo appeared in one article in our sample), it was not the metaphors themselves that were the cause for alarm. Instead, it was within the context of something really small being linked to terrorists and swarms of robots that would cause concern. This is was also found with regards to human hair in a New York Times article appearing on March 29, 2004.

Buckyballs, a spherical form of carbon discovered in 1985 and an important material in the new field of nanotechnology, can cause extensive brain damage in fish, according to research presented yesterday at a national meeting of the American Chemical Society in Anaheim, Calif.

Buckyballs are part of a group of materials called fullerenes for their structural resemblance to the geodesic domes designed by Buckminster Fuller. Synthetically produced buckyballs, along with more recently created fullerenes like carbon nanotubes, have played a major role in igniting interest in nanotechnology, the field in which researchers manipulate materials with dimensions measured in nanometers. A nanometer is a billionth of a meter -- tens of thousands of times thinner than a human hair.

The threat is not from human hair or buckyballs, both innocuous terms, but from the fact that the nanotubes were found to cause brain damage in scientific studies. In short, while this script is much different than those we mentioned before, the terms were the same. This is a reflection of Zelizer's [2] work that reporters are an interpretative community. The terms used in early articles continued to be used even when the coverage had changed focus (in this case from gee whiz science to potential harmful materials). To switch metaphors may have been seen as having to redefine nanotechnology.

The metaphors and scripts presented to this point have verged on science fiction, or at least been treated in ways that may make it hard to grasp for many people. There is one situation - an analogy and not a metaphor - that should be discussed that may be more real to some people. This is the link that began appearing between nanotechnology and asbestos. Asbestos is real and is known to cause cancer, leading government bodies in the US to fund asbestos removal in public buildings, including schools. On August 19, 2002, The New York Times published the following:

The great Gray Goo debate is beginning to matter.

The controversy involves the potential perils of making molecular-size objects and devices, a field known as nanotechnology.

The ultimate nightmare was the so-called Gray Goo catastrophe, in which self-replicating microscopic robots the size of bacteria fill the world and wipe out humanity.

Until recently, though, the debate was restricted to the relatively small community of nanotechnology researchers and experts. The risks they discussed often seemed cartoony or vague compared with the dazzling breakthroughs they projected in fields like medicine, supercomputing, energy and environmental cleanup.

The inventors of the technology saw numerous potential benefits from such sterility, including a reduced risk that other genetically engineered characteristics in plants -- like resistance to herbicides -- could escape into weeds. But the Rural Advancement Foundation and others saw the effort as an attempt by big business to make it impossible for small farmers to plant crops from seed they saved the previous year.

Some assert that research suggests that the characteristics that make carbon nanotubes and similar nanoscale particles attractive candidates for carrying drugs into the brain could also allow such particles to transport toxins. It quotes Dr. Mark Weisner, a Rice professor, as warning that nanotubes, because of their needle-like shape, could become "the next asbestos."

Notice the move from "cartoony" to "the next asbestos." The gray goo scenario - grounded in fantastical imagery gives way to a real threat - damaging particles that are compared to a known killer. If we are to return to our notion that the media do have an influence on audience members, it may be that these types of metaphors and analogies will have a larger impact than those grounded in symbols that hold little cultural resonance.

Two years later, The San Francisco Chronicle (July 26, 2004) also used the term asbestos in a story on nanotechnology, though notice the difference:

- Nanotechnology could revolutionize science, technology, medicine and space exploration.

- Nanotechnology could ravage the environment, eliminate jobs and lead to frightening new weapons of war. 
- Those are two extreme takes on the hottest, and potentially most controversial, new technology since biotech and PCs.

For years, science fiction writers and techno-visionaries have imagined the construction of "nano"-size -- one nanometer equals a billionth of a meter -- molecules and machines that could clean cholesterol from your bloodstream, break down chemical spills and lead to superstrong new materials. The late physicist Richard Feynman once said, "There's plenty of room at the bottom" - by which he meant humans could re-engineer atoms and molecules to do humanity's bidding.

But there have also been warnings of nano-machines that might race out of control, mass-replicating like bacteria and reducing Earth's surface into what a few nanotechnologists call a "gray goo".

Few experts take that scenario seriously, but in recent months, the less frightening potential health and environmental impacts of nano-gadgets have drawn increasing attention.

Insurance companies fear a repeat of the asbestos catastrophe, which resulted in a deluge of lawsuits from the 1970 s on and severely strained their coffers.

The scenarios still verge on science fiction, but notice that the concern with nanotechnology becoming the next asbestos is now linked to financial concerns within the insurance industry. There is still a tie to human health, but we also need to think about our insurance premiums. It should also be noted that both of these articles on nanotechnology and asbestos highlighted both the (potentially) positive and (potentially) negative aspects of this new science. Even facing the possibility of major human health concerns, journalists were unwilling to completely ignore the early trajectory of nanotechnology solving some of our major social problems.

\section{CONCLUSIONS}

Currently there are nearly 600 products (and counting) which use nanotechnology to some degree (http: //www. nanotechproject.org/inventories/consumer/analysis_draft/; accessed May 9, 2008), a number that has doubled in just a couple of years. This increase mirrored the reporting of nanotechnology between the late 1990s and early 2000s. In our study, we found a striking similarity across the country as to what was being said about this new technology, in which a majority of that coverage was positive. Through the media, nanotechnology was presented as a 'gee-whiz' science with few negative consequences (though some could be found as we showed with the link to asbestos). Given that few people have experiential knowledge of this technology, these scripts were likely to be very salient to anyone paying attention. Other technologies which have been promoted as safe have proven to be controversial (biotechnology, microwave ovens) or even dangerous (asbestos, various pharmaceuticals), so one could argue that at least some people would be skeptical of any "pie-in-the-sky" promises. Still, nanotechnology, with its links to human hair and soccer balls, seemed to be not only benign but a good thing for the US scientific community to pursue, and the US consumer to purchase when products became available.
Finally, the use of metaphors on this topic changed very little over time. This is interesting from both a reporting point of view in the sense that the interpretative community of journalism even maintains metaphors within a world of possibilities (think of all the things that are about as thick as a human hair - the stingers and legs of many insects, blades of grass, the webs of a spider, etc.). References to soccer balls and hairs could be found through most of the reporting, as well as terms such as small and tiny. This is also important when thinking about the media as a producer and disseminator of social scripts. If we are to believe Baudrillard [27] and other postmodernists, the media saturated society in which we live provides signs and signals for what is real (or hyper-real), and it is these signs and symbols to which the audience reacts and makes sense of their social environment. In a sense, nanotechnology does not exist except as the metaphors and analogies used by reporters. In addition, any potential scripts that currently do not exist (such as socioeconomic status and access to this technology) will be negative space - the term Ward and Winstanley [28] use to connote silence on a social issue. This, however, is more than silence. Silence in this sense connotes knowledge but unwillingness to express oneself. The negative space around nanotechnology may have aspects of silence involved, but is more a matter of ignorance. Without the metaphors and appropriate scripts, audience members will be led to think of nanotechnology in a homogenous way.

\section{REFERENCES}

[1] Zelizer B. Covering the Body. Chicago, IL: University of Chicago Press 1992.

[2] Zelizer B. Journalists as interpretive communities. Crit Stud Mass Commun 1993; 10: 219-37.

[3] Kim JL, Ward ML. Pleasure Reading: Associations between young women's sexual attitudes and their reading of contemporary women's magazines. Psychol Women Q 2004; 28: 48-58.

[4] Challener, C. Who's Doing What in Nanotechnology: Lubricants, personal care applications and composites are some of the latest developments topping nanotechnology R\&D and commercialization efforts. Chemical Market Reporter, April 28, 2003 (http://www.candmconsult.com/042803bChallener_RO.pdf, accessed November 7, 2008).

[5] Corcoran E. Mr. Nanotech. Forbes June 23, 2003 (http://www. forbes.com/forbes/2003/0623/128.html, accessed November 7, 2008).

[6] Henderson M. Cancer Fears Spark Call for Nanoscience Safety Rules. The Times 2004 (January 9).

[7] Shibata Y. How Safe if Nanotechnology? The Daily Yomiuri 2003; November 28: 4.

[8] Marc F [1914] in Chipp HB. Theories of Modern Art. Berkeley, CA: University of California Press 1968.

[9] Lee MA, Solomon N. Unreliable Sources. New York: Lyle Stuart 1990 .

[10] Thompson JB. Ideology and Modern Culture. Cambridge, MA: Polity 1990.

[11] Gaskell G, Bauer MW, Eds. Biotechnology, 1996-2000. London, UK: Science Museum 2001.

[12] Burnham JC. How Superstition Won and Science Lost. New Brunswick, NJ: Rutgers University Press 1987.

[13] Ten Eyck TA, Williment M. The more things change: milk pasteurization, food irradiation, and biotechnology in the New York Times. Soc Sci J 2004; 41: 29-41.

[14] Ten Eyck TA, Williment M. The national media and things genetic: coverage in The New York Times (1971 - 2000) and Washington Post, (1977-2000). Sci Comm 2003; 25: 129-52.

[15] Ericson RV, Baranek PM, Chan JBL. Negotiating Control. Toronto: University of Toronto Press 1989.

[16] Tuchman G. Making News. New York: The Free Press 1978. 
[17] Gerbner G, Gross L, Morgan M, Signorielli N. The 'Mainstreaming' of America: Violence profile no. 11. J Comm 1980; 30: 10-29.

[18] Pratkanis A, Aronson E. Age of Propaganda (revised edition). New York: Henry Holt 2001.

[19] Gaskell G, Ten Eyck TA, Jackson J, Veltri G. "Public Attitudes to Nanotechnology in Europe and the United States." Nat Mater 2004; 3: 496

[20] Goffman E. The Presentation of Self in Everyday Life. New York: Doubleday 1959.

[21] Gamson WA. Talking Politics. New York: Cambridge University Press 1992.

[22] Jenner A, Scott A. Circulating beliefs, resilient metaphors, and faith in biomedicine: hepatitis $\mathrm{C}$ patients and interferon combination therapy. Sociol Health Illn 2008; 30: 197-216.

[23] Gans HJ. Deciding What's News. New York: Vintage 1979.

[24] Priest SH, Ten Eyck TA. Transborder Information, Local Resistance, and the Spiral of Silence: Biotechnology and Public Opinion in the United States. In: Braman S, Ed. Biotechnology and
Communication: The meta-technologies of information, Lawrence Erlbaum Associates 2004, pp. 175-196

Best J. 'Road Warriors' on 'Hair-Trigger Highways': Cultural resources and the media's construction of the 1987 freeway shootings problem. Socio Inq 1991; 61: 327-45.

[26] Ten Eyck TA. The Marginalization of Food Safety Issues: An interpretative approach to popular mass media coverage. J App Comm 2000; 84: 29-47.

[27] Baudrillard J. For a critique of the political economy of the sign (trans. by Charles Levin). St. Louis: Telos 1981

[28] Ward J, Winstanley D. The absent presence: negative space within discourse and the construction of minority sexual identity in the workplace. Hum Relat 2003; 56: 1255-80.

[29] Time. 2000, June 19. "What is Nanotechnology?" 155, 25: 95.

[30] Garfinkel H. Studies in Ethnomethodology. Malden, MA: Polity Press 1967.

(C) Eyck and Hernandez; Licensee Bentham Open

This is an open access article licensed under the terms of the Creative Commons Attribution Non-Commercial License (http: //creativecommons.org/licenses/by$\mathrm{nc} / 3.0 /$ ), which permits unrestricted, non-commercial use, distribution and reproduction in any medium, provided the work is properly cited. 